\title{
Impact of board structure on firm performance: evidence from an emerging economy
}

\author{
Qaiser Rafique Yasser, Abdullah Al Mamun and Marcus Rodrigs
}

\author{
Qaiser Rafique Yasser is \\ based at the Faculty of \\ Economics and Business, \\ University Malaysia \\ Sarawak, Kuching, \\ Malaysia. \\ Abdullah Al Mamun and \\ Marcus Rodrigs both are \\ based at the Newcastle \\ Business School, \\ University of Newcastle, \\ Newcastle, Australia.
}

Received 9 June 2015 Revised 10 September 2015 18 November 2015 7 February 2016 16 April 2016 Accepted 3 May 2016

\begin{abstract}
Purpose - The aim of this paper is to examine the association between board demographics and firm financial performance of Karachi Stock Exchange companies and describe the attributes of these firms and their boards. The connection between board structure and firm performance has attracted much attention, especially in emerging economies, yet yielded many inconsistent empirical results.

Design/methodology/approach - This study examines the relationship between board structure and the performance of Pakistani public listed companies by using a sample of Karachi Stock Exchange 100 (KSE-100) indexed companies. This study exploits the corporate performance by accounting-based measures (return on assets), market-based measures (Tobin's $Q$ ), and economic profit (economic value added).

Findings - The outcome of the study shows the positive relationship between the board size, minority representation in board, and family director's in-board and firm performance. The authors also find that, instead of adding value, independent directors in Pakistan are negatively associated with firm value.

Research limitations/implications - The study is based on KSE-100 indexed companies from 2009 to 2013; however, a large sample and multiple years' data are required.

Practical implications - The paper provides empirical evidence that board independence is not necessary for public-listed companies in Pakistan and would be of interest to regulatory bodies, business practitioners, and academic researchers.

Originality/value - The paper contributes to the literature on corporate governance and firm performance by introducing a framework for identifying and analyzing moderating variables that affect the relationship between board structure and firm performance.

Keywords Corporate governance, Board of director

Paper type Research paper

\section{Introduction}

It is generally accepted that corporate boards participate a fundamental role in corporate governance, the structure of the strategic dimensions of the company and originate goals (Agyemang et al., 2014). However, there is no consensus as to what the optimal board structure should be (Agyemang and Castellini, 2013). There is fluid controversy on whether the board should be composed mainly of "inside" or "outside" directors (Hermalin and Weisbach, 2003; Nicholson and Kiel, 2007; Kaymak and Bektas, 2008). The agency theorist argues that board independence is essential if it is monitored effectively by management team, and insider-dominated boards, by their very nature, are not independent of the management (Heravia et al., 2011). Besides, steward theorist argues that inside directors are more effective because they have better knowledge of the company and industry than outside directors and they are just as diligent as non-executive directors, given their legal responsibility and their own vested interest in the firm (Dalton and Dalton, 2005; Zhang and Wang, 2013).
\end{abstract}

